\title{
Vitamin D receptor rs2228570 polymorphism is associated with LH levels in men exposed to anabolic androgenic steroids
}

\author{
Linda Björkhem-Bergman ${ }^{1 *}$, Mikael Lehtihet ${ }^{2}$, Anders Rane ${ }^{3}$ and Lena Ekström ${ }^{3}$
}

\begin{abstract}
Objective: The primary aim of this study was to investigate the association between the vitamin $\mathrm{D}$ receptor polymorphisms rs2228570 (Fok1) and rs731236 (Taql) and LH and FSH levels in relation to anabolic androgenic steroid (AAS) use.

Results: Two cohorts were analyzed. Cohort 1 comprised healthy volunteers given single supra-physiological doses of $500 \mathrm{mg}$ testosterone $(n=25)$. Cohort 2 comprised 45 self-reporting AAS users. Healthy volunteers homozygous for the C-allele of the Fok1 polymorphism exhibited 30\% higher LH levels than T-carriers at baseline $(p=0.04)$ and twice the levels 14 days after testosterone administration $(p=0.01)$. AAS users homozygous for the $\mathrm{C}$-allele had four times higher LH levels than TT-individuals ( $p<0.05)$. FSH levels were not associated with Fok1 polymorphism, nor were LH and FSH levels associated with the Taql polymorphism. In conclusion, there is an association between LH levels and the Fok1 VDR polymorphism and this difference is even more pronounced in AAS users and subjects with suppressed LH levels.
\end{abstract}

Keywords: Vitamin D receptor, rs2228570, rs731236, Anabolic androgenic steroid, Hypogonadism, LH, FSH

\section{Introduction}

It is generally known that the use of anabolic androgenic steroids (AAS) suppresses the secretion of the pituitary luteinizing hormone $(\mathrm{LH})$ and follicle stimulating hormone (FSH). This effect results from a negative feedback of androgens on the hypothalamic-pituitary-gonadal (HPG) axis. We recently showed that already a single dose of intra-muscular administration of testosterone or nandrolone suppresses the secretion of LH and FSH, but with large inter-individual variations $[1,2]$. After discontinuation of AAS use, LH and FSH may be suppressed for a long period of time, resulting in anabolic steroid induced hypogonadism (ASIH) [3]. The time of AAS induced hypogonadotropic hypogonadism is highly variable and is dependent on the duration, dose and type of

\footnotetext{
*Correspondence: linda.bjorkhem-bergman@ki.se

${ }^{1}$ Division of Clinical Microbiology F68, Department of Laboratory Medicine, Karolinska University Hospital, Karolinska Institutet, Huddinge, 14186 Stockholm, Sweden

Full list of author information is available at the end of the article
}

steroids used, co-use of other drugs and age, but may also be influenced by genetic factors [4-6].

Several studies have shown that vitamin D deficiency is associated with low testosterone levels in men $[5,7]$ which may be accompanied by low levels of gonadotropins [8]. Vitamin D exhibits its effect by binding to the vitamin D receptor (VDR). A previous study reported that a single nucleotide polymorphism (SNP) rs731236 (also known as TaqI) in VDR was associated with serum LH concentration but not with FSH concentrations in women with polycystic ovarian syndrome (PCOS) [9]. This polymorphism is a silent $\mathrm{T}>\mathrm{C}$ SNP located in exon 9 and affects the function of VDR, probably due to an altered expression profile [10].

The VDR genotype rs2228570 (also known as Fok1) is a $\mathrm{C}>\mathrm{T}$ non-synonymous polymorphism situated in the translation start site of VDR. The $\mathrm{C}$ variant results in a truncated protein, 3 amino acids shorter, with higher activity [11]. Studies have shown that carriers of the $\mathrm{T}$ variant, expressing a VDR-protein with lower activity, are more susceptible to different cancer forms, including 
ovarian cancer [12-15], and have an impaired immune system $[16,17]$. However, this SNP has never been studied in relation to $\mathrm{LH}$ and FSH concentrations.

The aim of this pilot-study was to investigate the association between VDR rs2228570 and rs731236 polymorphisms and the levels of LH and FSH in relation to AAS use. To this end post hoc analysis of material from two previous performed studies were used.

\section{Main text \\ Methods}

Two cohorts of individuals were included; healthy volunteers given supra-physiological doses of testosterone $(\mathrm{n}=25)$ and one group of self-reporting AAS users $(\mathrm{n}=45)$. The study population of cohort 1 has been described earlier and included 25 male volunteers aged 27-43 years [2]. The participants were given a single intramuscular dose of $500 \mathrm{mg}$ testosterone enanthate (Testoviron ${ }^{\circledR}$ Depot) with the primary end-point to study different doses of testosterone and doping analysis in urine samples [18]. Exclusion criteria in the study were ongoing hormonal therapy treatment, treatment with NSAID, positive for hepatitis or HIV, being under the influence of abused substances, member of a Sports federation, malignancy within the last 5 years prior to study entry or allergy towards the compounds given. Blood samples were collected prior to (Day 0), and 4 and 14 days after testosterone administration. Blood samples were collected between $7.00 \mathrm{am}$ and $9.00 \mathrm{am}$ after an overnight fast. Cohort 2 consisted of AAS abusers between 18 and 57 years old. They were recruited to a previous study performed at our unit between 1993 and 2000 where men were asked to participate when they contacted the AntiDoping Hot-Line, a free telephone counseling service for individuals abusing AAS [19]. A genuine desire to give up the abuse was a prerequisite to be included. Participation was commenced after informed consent, and no economical remuneration was given to the participants. A flow chart of the recruitment process has been published elsewhere [20]. Exclusion criteria in this study were not willing to stop their AAS abuse or not fluent in Swedish. Urine samples were collected and $84 \%$ of the participants were positive on AAS. The participants were clinically investigated and a series of endocrine parameters including LH and FSH were monitored in blood samples that were collected at the inclusion of the study.

LH and FSH were determined with accredited methods at the division of clinical pharmacology, at the time when the respective study was performed. In cohort 1 (analysed in 2014), FSH was measured by an immunochemical method on a Roche Cobas e602 after preparation with Elecsys FSH reagent kit (Cat no 11775863, Roche). LH was measured with AutoDELFIA using a AutoDELFIA
hLH Spec kit (Cat No. 11732234, Perkin Elmer). Both methods had a lower detection limit of $0.05 \mathrm{IU} / \mathrm{l}$. The samples from study 2 (analysed in 2000) were determined with electrochemiluminescence (Cobas 8000, Roche Diagnostics) with a lower detection limit $0.7 \mathrm{IU} / \mathrm{l}$. The information of kits used at that time is not available.

Genomic DNA was isolated from $200 \mu \mathrm{l}$ peripheral blood (Cohort 1) and from serum (Cohort 2) using the DNA Blood Mini kit (Cat No. 51104; Qiagen, Hilden Geramany). Allelic discrimination reactions were performed using TaqMan ${ }^{\circledR}$ genotyping assays (Cat No. 4351379; Applied Biosystems, Foster City CA USA): C_12060045_20 for VDR (rs2228570); C__2404008_10 for VDR (rs731236). The final volume of each reaction was $10 \mu \mathrm{l}$ consisting of $10-30 \mathrm{ng}$ DNA and $2 \times$ Taqman Universal PCR Master mix (LifeTechnology, Applied Biosystems, Catalog no 4440047). The PCR profile consisted of $95{ }^{\circ} \mathrm{C}$ for 10 min followed by 40 cycles of $92{ }^{\circ} \mathrm{C}$ for $15 \mathrm{~s}$ and $60^{\circ} \mathrm{C}$ for $1 \mathrm{~min}$. The fluorescence signal was measured with an ABI 7500 Sequence detector (Applied Biosystems).

All statistical tests were performed using GraphPad Prism (San Diego, California, USA) v. 6.00 and values of $\mathrm{p} \leq 0.05$ were considered statistically significant. Since the hormone levels of gonadotropins are not normally distributed, non-parametric Mann-Whitney U test was used.

\section{Results}

In Cohort 1 the genotype frequencies were Fok1 $\mathrm{CC}=53 \%, \mathrm{TC}=26 \%$ and $\mathrm{TT}=21 \%$ and for TaqI $\mathrm{TT}=37 \%, \mathrm{TC}=63 \%$ and $\mathrm{CC}=0 \%$, respectively. The Fok1 polymorphism was associated with the LH concentration at baseline as well as after 4 and 14 days after the testosterone dose. Individuals homozygous for CC had 30\% higher LH concentration at baseline compared to T-carriers; mean $4.2 \pm 0.9$ compared to $3.2 \pm 1.2$ $(\mathrm{p}=0.04)$. At 4 and 14 days, the LH concentrations were approximately twice as high in the $\mathrm{CC}$ subjects compared to the T-carriers; mean $1.5 \pm 1.3$ and $0.33 \pm 0.29$ compared to $0.73 \pm 0.71$ and $0.18 \pm 0.10,(\mathrm{p}=0.04$ and $\mathrm{p}=0.01$ ) (Fig. 1). There was no association between the Fok1 SNP and FSH concentration at any time (Fig. 1). The TaqI VDR genotype (rs731236) was not associated with $\mathrm{LH}$ and FSH concentrations at any of the time points (Fig. 1). The genotype frequencies of both SNPs were in Hardy-Weinberg (HW) equilibrium.

In order to confirm the findings in Cohort 1 we genotyped samples obtained from AAS users. When the subjects showed up for the first visit, serum samples were collected. The time span from their last intake of AAS varied between a few days and some months. The genotype frequencies of TaqI were $\mathrm{TT}=49 \%, \mathrm{TC}=42 \%$ and 

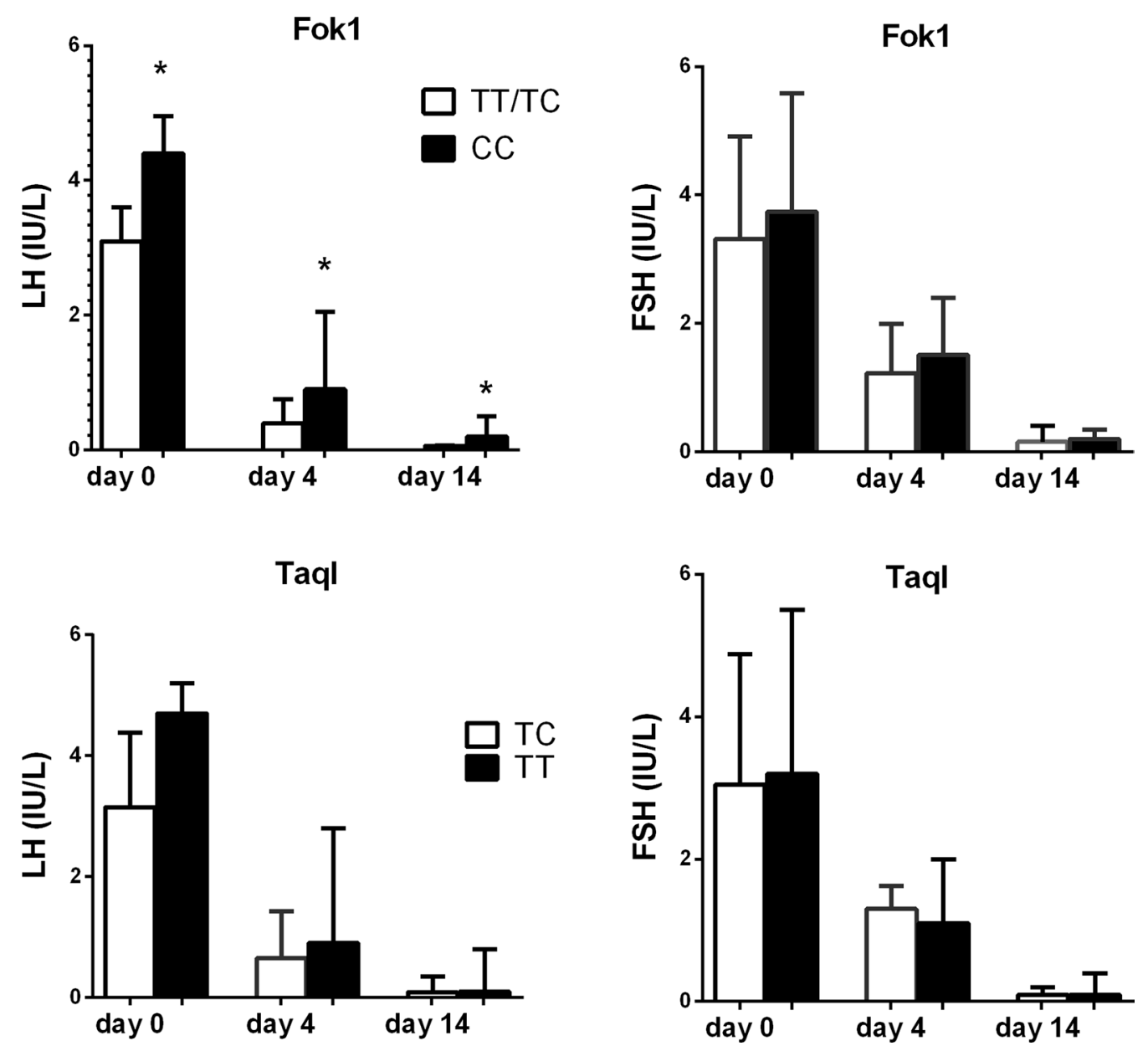

Fig. 1 The suppression of $\mathbf{a} \mathrm{LH}$ and $\mathbf{b}$ FSH 4 and 14 days after the administration of testosterone (cohort 1, $\mathrm{n}=19$ ) in relation to VDR Fok1 (rs222857 $\mathrm{C}<\mathrm{T}$ ) and Taql (rs731236 T < C) SNPs. Column shows mean values and bars SD. ${ }^{*} \mathrm{p}<0.05$

Table 1 LH and FSH concentrations (mean \pm SD) in selfreporting AAS users from cohort $2(n=45)$ in relation to VDR rs2228570 polymorphism

\begin{tabular}{lll}
\hline VDR Genotype & LH (IU/I) & FSH (IU/I) \\
\hline rs2228570 & & \\
TT $(n=7)$ & $0.60( \pm 0.60)$ & $0.35( \pm 2.24)$ \\
TC $(n=21)$ & $1.68( \pm 1.35)$ & $1.40( \pm 1.82)$ \\
CC $(n=17)$ & $2.20( \pm 0.59)^{*}$ & $1.20( \pm 1.34)$ \\
\hline
\end{tabular}

CC-individuals had statistical significant higher LH-levels compared to individuals carrying the T-allele

$* p<0.05$

$\mathrm{CC}=9 \%$ and for Fok1 see Table 1 . In summary, the $\mathrm{LH}$ levels were significantly lower than the baseline levels observed in the healthy volunteers $(\mathrm{p}<0.001)$ as a result of their AAS use. A significant association between the Fok1 VDR polymorphism and the LH concentration was found also in Cohort 2, whereas no association was found between this SNP and the FSH concentration (Table 1). Individuals homozygous for the C-allele had significantly higher LH levels than carriers of the T-allele $(\mathrm{p}<0.05)$ and four times higher levels than TT-individuals $(\mathrm{p}<0.05)$. The genotype frequency of rs2228570 was in HW equilibrium, whereas the genotype frequency of rs731236 was not $(\mathrm{p}=0.04)$.

\section{Discussion}

The results from this study show that individuals homozygous for the T-allele of the VDR polymorphism Fok1 (rs2228570) have lower circulatory LH levels than carriers of the $\mathrm{C}$-allele in two different populations. The difference in $\mathrm{LH}$ concentration between the genotype groups was larger after the administration of a supraphysiological dose of testosterone and in self-reporting AAS users as compared to baseline values. This is the 
first time a VDR polymorphism is shown to be associated with serum levels of $\mathrm{LH}$ in relation to AAS use.

The Fok1 (rs558750) C-allele leads to a truncated protein, three amino acids shorter than the wildtype T-variant. The C-allele has been associated with higher activity in vitro [11]. Subjects with the T-allele, i.e. expressing the protein with lower activity, have been shown to have increased risk of hormonal dependent cancers, such as ovarian [14, 21] and prostate cancer [22]. The association with breast cancer seems to be weaker and different studies have shown divergent results [23-25].

It has previously been reported that serum LH concentrations in women with PCOS are associated with the VDR TaqI (rs731236) polymorphism [9]. PCOS is a disorder where women have naturally higher concentrations of circulatory androgens as well as LH $[26,27]$. We could not find any association between the rs731236 polymorphism and gonadotropin concentrations in the cohorts studied here. It is possible that the VDR genotypes exert different gender and/or disorder effects [28]. Based on these data it seems that androgens, whether endogenous or exogenous seem to amplify the genetic association with the circulatory LH concentrations. A recent GWAS study including 2913 individuals (294 males) identified that a genetic variant near the FSHB gene was associated with LH levels [29].

LH is produced exclusively in the gonadotropic cells of the anterior pituitary. VDR is abundant in the human pituitary [30] and it is plausible that VDR may be involved in the synthesis of gonadotropins and that the more efficient VDR C-allele is associated with an increased transcriptional activity of genes required for the synthesis of LH subunits. FSH levels were not affected by the VDR polymorphism. FSH is partly regulated by other mechanisms than LH. For example, inhibin and activin from the sertoli cells affects the FSH levels independently of androgens.

Several studies have shown that vitamin D deficiency is associated with low testosterone levels in men $[5,7]$, which may be accompanied by low levels of gonadotropins [8]. Wehr et al. hypothesized that vitamin D may have an impact directly on the gonadal function since testosterone and vitamin $\mathrm{D}$ displayed a concordant seasonal pattern [31]. Moreover supplementation with vitamin D increases the total testosterone levels in some studies [32]. Therefore, it is of clinical interest to further investigate how vitamin D and the VDR mediated effect is involved in the regulation of the HPG-axis.

Supra-physiological doses of androgens are known to suppress LH and FSH with a fast response that may persist for a long time [3]. The resulting hypogonadism has been associated with the more distressing AAS induced side effects, such as depression and sexual dysfunction
[33, 34]. The degree of suppression and the ability to recover after an AAS cycle depends on the duration of AAS use and the cumulative dose [35].

However, these findings are not only of interest in relation to AAS abuse but also to men with iatrogenicaly suppressed LH-levels, as in prostate cancer patients on hormonal therapy. Indeed, the Fok1 VDR polymorphism has been associated with the prognosis in prostate cancer [36]. If the results presented here also apply to women it may indicate that subjects homozygous for the T-allele would have an even higher suppression of their LH-levels when taking contraceptives than in subjects with the $\mathrm{C}$-allele. The results might also contribute to the understanding of the increased risk of ovarian cancers in women with the T-allele $[14,21]$.

In conclusion, we show an association between LH levels and the Fok1 VDR polymorphism and that this difference is even more pronounced in AAS users and subjects with suppressed LH levels. The role of VDR in the synthesis and secretion of LH warrants further studies.

\section{Limitations}

This study has some limitations that need to be considered. The population included male subjects who self-reported AAS use, different doses and administration routes have been used, and the time elapsed since their last AAS intake varied between some days to some months. However, it is not possible to conduct a controlled study using the high doses AAS users normally use. In human studies, lower doses and/or single doses are given. Another limitation is the small number of subjects included. Still, the same findings are present in both cohorts although they are collected with more than 10 years in between. The hormone analysis in Cohort 2 was analyzed in year 2000 and the method used at this time was not as sensitive as the methods used today. The lower detection limit for LH was then only $0.7 \mathrm{IU} / \mathrm{l}$. It is possible that with a more sensitive method employed today an even larger association of the Fok1 genotype and LH secretion could have been discerned.

\section{Abbreviations \\ AAS: anabolic androgenic steroids; ASIH: anabolic steroid induced hypog- onadism; FSH: follicle stimulating hormone; LH: luteinizing hormone; SNP: single nucleotide polymorphism; VDR: vitamin D receptor.}

\section{Authors' contributions}

LBB and LE designed the study, performed the analysis and wrote the first draft of the manuscript. ML and AR conducted the original studies (cohort 1 and 2), were involved in the interpretation of the data and contributed to the writing of the final version of the manuscript. All authors read and approved the final manuscript.

\section{Author details}

${ }^{1}$ Division of Clinical Microbiology F68, Department of Laboratory Medicine, Karolinska University Hospital, Karolinska Institutet, Huddinge, 141 
86 Stockholm, Sweden. ${ }^{2}$ Department of Medicine, Division of Endocrinology, Metabolism and Diabetesm Karolinska Institutet, Karolinska University Hospital, Huddinge, 14186 Stockholm, Sweden. ${ }^{3}$ Division of Clinical Pharmacology, Department of Laboratory Medicine, Karolinska Institute, Karolinska University Hospital, Huddinge, 14186 Stockholm, Sweden.

\section{Acknowledgements}

The authors are grateful to Dr. Nina Gårevik for excellent work with the clinical studies in this project.

\section{Competing interests}

The authors declare that they have no competing interests.

\section{Availability of data and materials}

Raw data are available from the corresponding author upon request.

\section{Consent for publication}

Not applicable.

\section{Ethics approval and consent to participate}

Both studies $[2,19]$ were approved by the Regional Ethical Committee at Karolinska Institutet and performed in accordance with Declaration of Helsinki, Dnr 186/98 and 2008/187-31. Study 1 were also approved by the Swedish Medical Product Agency. Written informed consent was obtained from all participants before inclusion in the studies.

\section{Funding}

Financial support was provided through the Regional agreement on training and clinical research (ALF) between Karolinska Institutet and Stockholm County Council, The Swedish Cancer Society and Karolinska Institutet.

\section{Publisher's Note}

Springer Nature remains neutral with regard to jurisdictional claims in published maps and institutional affiliations.

Received: 5 November 2017 Accepted: 12 January 2018

Published online: 19 January 2018

\section{References}

1. Garevik N, Borjesson A, Choong E, Ekstrom L, Lehtihet M. Impact of single-dose nandrolone decanoate on gonadotropins, blood lipids and HMG CoA reductase in healthy men. Andrologia. 2016:48(5):595-600.

2. Garevik N, Rane A, Bjorkhem-Bergman L, Ekstrom L. Effects of different doses of testosterone on gonadotropins, 25-hydroxyvitamin D3, and blood lipids in healthy men. Subst Abuse Rehabil. 2014;5:121-7.

3. Jarow JP, Lipshultz LI. Anabolic steroid-induced hypogonadotropic hypogonadism. Am J Sports Med. 1990;18(4):429-31.

4. Flanagan $\mathrm{JN}$, Lehtihet $\mathrm{M}$. The response to gonadotropin-releasing hormone and hCG in men with prior chronic androgen steroid abuse and clinical hypogonadism. Horm Metab Res. 2015;47(9):668-73.

5. Lee DM, Tajar A, Pye SR, Boonen S, Vanderschueren D, Bouillon R, O'Neill TW, Bartfai G, Casanueva FF, Finn JD, et al. Association of hypogonadism with vitamin D status: the European Male Ageing Study. Eur J Endocrinol. 2012;166(1):77-85.

6. Turillazzi E, Perilli G, Di Paolo M, Neri M, Riezzo I, Fineschi V. Side effects of AAS abuse: an overview. Mini Rev Med Chem. 2011;11(5):374-89.

7. Nimptsch K, Platz EA, Willett WC, Giovannucci E. Association between plasma 25-OH vitamin D and testosterone levels in men. Clin Endocrinol. 2012;77(1):106-12.

8. Wang N, Han B, Li Q, Chen Y, Chen Y, Xia F, Lin D, Jensen MD, Lu Y. Vitamin $D$ is associated with testosterone and hypogonadism in Chinese men: results from a cross-sectional SPECT-China study. Reprod Biol Endocrinol. 2015;13:74.

9. Ranjzad F, Mahban A, Shemirani Al, Mahmoudi T, Vahedi M, Nikzamir A, Zali MR. Influence of gene variants related to calcium homeostasis on biochemical parameters of women with polycystic ovary syndrome. J Assist Reprod Genet. 2011;28(3):225-32.
10. Morrison NA, Qi JC, Tokita A, Kelly PJ, Crofts L, Nguyen TV, Sambrook PN, Eisman JA. Prediction of bone density from vitamin $D$ receptor alleles. Nature. 1994;367(6460):284-7.

11. Arai H, Miyamoto $K$, Taketani $Y$, Yamamoto $H$, lemori $Y$, Morita $K$, Tonai T, Nishisho T, Mori S, Takeda E. A vitamin D receptor gene polymorphism in the translation initiation codon: effect on protein activity and relation to bone mineral density in Japanese women. J Bone Miner Res. 1997;12(6):915-21.

12. Kaabachi W, Kaabachi S, Rafrafi A, Amor AB, Tizaoui K, Haj Sassi F, Hamzaoui K. Association of vitamin D receptor Fokl and Apal polymorphisms with lung cancer risk in Tunisian population. Mol Biol Rep. 2014;41(10):6545-53.

13. Li L, Shang F, Zhang W, Zhang C, Li J, Wang C, Wei L. Role of vitamin D receptor gene polymorphisms in pancreatic cancer: a case-control study in China. Tumour Biol. 2015;36(6):4707-14.

14. Li S, Xu H, Li SC, Qi XQ, Sun WJ. Vitamin D receptor rs2228570 polymorphism and susceptibly to ovarian cancer: a meta-analysis. Tumour Biol. 2014;35(2):1319-22.

15. Peng Q, Yang S, Lao X, Li R, Chen Z, Wang J, Qin X, Li S. Association of single nucleotide polymorphisms in VDR and DBP genes with HBVrelated hepatocellular carcinoma risk in a Chinese population. PLoS ONE. 2014:9(12):e116026.

16. Roth $D E$, Jones $A B$, Prosser $C$, Robinson JL, Vohra S. Vitamin D receptor polymorphisms and the risk of acute lower respiratory tract infection in early childhood. J Infect Dis. 2008;197(5):676-80.

17. van Etten E, Verlinden L, Giulietti A, Ramos-Lopez E, Branisteanu DD, Ferreira GB, Overbergh L, Verstuyf A, Bouillon R, Roep BO, et al. The vitamin $D$ receptor gene Fokl polymorphism: functional impact on the immune system. Eur J Immunol. 2007;37(2):395-405.

18. Strahm E, Mullen JE, Garevik N, Ericsson M, Schulze JJ, Rane A, Ekstrom L. Dose-dependent testosterone sensitivity of the steroidal passport and GC-C-IRMS analysis in relation to the UGT2B17 deletion polymorphism. Drug Test Anal. 2015;7(11-12):1063-70.

19. Eklof AC, Thurelius AM, Garle M, Rane A, Sjoqvist F. The anti-doping hot-line, a means to capture the abuse of doping agents in the Swedish society and a new service function in clinical pharmacology. Eur J Clin Pharmacol. 2003;59(8-9):571-7.

20. Garevik N, Strahm E, Garle M, Lundmark J, Stahle L, Ekstrom L, Rane A. Long term perturbation of endocrine parameters and cholestero metabolism after discontinued abuse of anabolic androgenic steroids. J Steroid Biochem Mol Biol. 2011;127(3-5):295-300.

21. Lurie G, Wilkens LR, Thompson PJ, Carney ME, Palmieri RT, Pharoah PD, Song H, Hogdall E, Kjaer SK, DiCioccio RA, et al. Vitamin D receptor rs2228570 polymorphism and invasive ovarian carcinoma risk: pooled analysis in five studies within the Ovarian Cancer Association Consortium. Int J Cancer. 2011;128(4):936-43.

22. Zhang Q, Shan Y. Genetic polymorphisms of vitamin D receptor and the risk of prostate cancer: a meta-analysis. J BUON. 2013;18(4):961-9.

23. Anderson LN, Cotterchio M, Cole DE, Knight JA. Vitamin D-related genetic variants, interactions with vitamin $D$ exposure, and breast cancer risk among Caucasian women in Ontario. Cancer Epidemiol Biomarkers Prev. 2011;20(8):1708-17

24. Dorjgochoo T, Delahanty R, Lu W, Long J, Cai Q, Zheng Y, Gu K, Gao YT, Zheng W, Shu XO. Common genetic variants in the vitamin D pathway including genome-wide associated variants are not associated with breast cancer risk among Chinese women. Cancer Epidemiol Biomarkers Prev. 2011;20(10):2313-6.

25. McKay JD, McCullough ML, Ziegler RG, Kraft P, Saltzman BS, Riboli E, Barricarte A, Berg CD, Bergland G, Bingham S, et al. Vitamin D receptor polymorphisms and breast cancer risk: results from the National Cancer Institute Breast and Prostate Cancer Cohort Consortium. Cancer Epidemiol Biomarkers Prev. 2009:18(1):297-305.

26. Akram M, Roohi N. Endocrine correlates of polycystic ovary syndrome in Pakistani women. J Coll Physicians Surg Pak. 2015;25(1):22-6.

27. Bungum L, Franssohn F, Bungum M, Humaidan P, Giwercman A. The circadian variation in Anti-Mullerian hormone in patients with polycystic ovary syndrome differs significantly from normally ovulating women. PLOS ONE. 2013;8(9):e68223.

28. Laczmanski L, Lwow F, Mossakowska M, Puzianowska-Kuznicka M, Szwed M, Kolackov K, Krzyzanowska-Swiniarska B, Bar-Andziak E, Chudek J, Sloka $\mathrm{N}$, et al. Association between vitamin $\mathrm{D}$ concentration and levels of sex 
hormones in an elderly Polish population with different genotypes of VDR polymorphisms (rs10735810, rs1544410, rs7975232, rs731236). Gene. 2015;559(1):73-6.

29. Ruth KS, Campbell PJ, Chew S, Lim EM, Hadlow N, Stuckey BG, Brown SJ, Feenstra B, Joseph J, Surdulescu GL, et al. Genome-wide association study with 1000 genomes imputation identifies signals for nine sex hormonerelated phenotypes. Eur J Hum Genet. 2016;24(2):284-90.

30. Perez-Fernandez R, Alonso M, Segura C, Munoz I, Garcia-Caballero T, Diguez C. Vitamin D receptor gene expression in human pituitary gland. Life Sci. 1997;60(1):35-42.

31. Wehr E, Pilz S, Boehm BO, Marz W, Obermayer-Pietsch B. Association of vitamin D status with serum androgen levels in men. Clin Endocrinol. 2010;73(2):243-8.

32. Pilz S, Frisch S, Koertke H, Kuhn J, Dreier J, Obermayer-Pietsch B, Wehr E, Zittermann A. Effect of vitamin D supplementation on testosterone levels in men. Horm Metab Res. 2011;43(3):223-5.
33. Coward RM, Rajanahally S, Kovac JR, Smith RP, Pastuszak AW, Lipshultz LI. Anabolic steroid induced hypogonadism in young men. J Urol. 2013;190(6):2200-5.

34. Parkinson AB, Evans NA. Anabolic androgenic steroids: a survey of 500 users. Med Sci Sports Exerc. 2006;38(4):644-51.

35. Tan RS, Scally MC. Anabolic steroid-induced hypogonadism-towards a unified hypothesis of anabolic steroid action. Med Hypotheses. 2009; 72(6):723-8

36. Pao JB, Yang Y Y, Huang CN, Huang SP, Hour TC, Chang TY, Lan YH, LuTL, Lee $\mathrm{HZ}$, Juang $\mathrm{SH}$, et al. Vitamin D receptor gene variants and clinical outcomes after androgen-deprivation therapy for prostate cancer. World J Urol. 2013;31(2):281-7.

\section{Submit your next manuscript to BioMed Central and we will help you at every step:}

- We accept pre-submission inquiries

- Our selector tool helps you to find the most relevant journal

- We provide round the clock customer support

- Convenient online submission

- Thorough peer review

- Inclusion in PubMed and all major indexing services

- Maximum visibility for your research

Submit your manuscript at www.biomedcentral com/submit 